\title{
Control of manganese deficiency in sugar beet by placement of a manganated compound fertilizer
}

\author{
MATTI ERJALA \\ Sugar Beet Research Centre, \\ SF-25170 KOTALATO, Finland
}

\begin{abstract}
In Finland, manganese deficiency in sugar beet has traditionally been controlled by spraying the foliage with manganese sulphate. According to field experiments, placement of an acid compound fertilizer seems to provide a new possibility of controlling manganese deficiency of sugar beet in heavily limed fields. In 1-year experiments carried out in 1984-1985 in seven fields which showed slight symptoms of manganese deficiency, conversion from top dressing to the placement technique alone increased the availability of soil manganese to sugar beet. The availability was, however, best safeguarded only when manganese $(0.7 \%)$ was added to acid compound fertilizer and applied by the placement technique. Placement of manganese $\left(25-30 \mathrm{~kg} / \mathrm{ha} \mathrm{MnSO}_{4} ; \mathrm{Mn} 26 \%\right.$ ) together with acid compound fertilizer increased the root yield by 2.0 tons $(+7 \%)$ per hectare in average compared to placement of manganese-free compound fertilizer. The new method of application did not have a significant effect on the quality of sugar beet.
\end{abstract}

Index words: manganese fertilization, fertilizer reaction, band applied manganese

\section{Introduction}

Manganese, a nutrient that plants need minimal quantities of, has been a well-known plant nutrient for over 60 years (McHARGUE 1922). According to some studies, a sugar beet yield of 35 tons/hectare only contains $2000 \mathrm{~g}$ of manganese in average, including the tops (DRAYCOTT 1972).

In Finland, the sugar beet soils normally contain much more manganese than a crop needs, but unfortunately most of the manganese is not in a plant-available form (MĀNTYLAHTI 1981, SPERLINGSSON 1982). Like other plants, sugar beet can only make use of manganese in the form $\mathrm{Mn}^{2+}$ either as such (Cheng and Ouellette 1971) or small quantities of organic complex compounds of man- ganese (Garcia and Sanchez de La Puente 1977).

The quantity of plant-available manganese is affected by several external factors; available manganese can take an inavailable form or vice versa. This is a typical equilibrium reaction that can be illustrated by the following oxidation-reduction equation (SCHEFFER and SCHACHTSCHABEL 1976):

$\mathrm{MnO}_{2}+4 \mathrm{H}^{+}+2 \mathrm{e}^{-}=\mathrm{Mn}^{2+}+2 \mathrm{H}_{2} \mathrm{O}$

(inavailable manganese $\rightleftarrows$ available manganese)

According to the above equation, the quantity of manganese available to plants can be 
controlled by the acidity and the redox-potential of the soil.

In Finland, the cultivated soil is naturally acid. In sugar beet cultivation these soils require heavy liming, because sugar beet grows well in neutral soil. Liming decreases the acidity of the soil, but makes manganese partly inavailable to plants. Heavy liming can cause manganese deficiency which is in fact a very common situation in Finland.

Fertilizers that increase soil acidity counteract liming. These fertilizers release manganese for the use of plants (Solovjev and Golubev 1978). The usefulness of this information is, however, only theoretical, because acidification of the whole growth bed by fertilizers would be very expensive. The soil $\mathrm{pH}$ can, however, be lowered locally. For instance, by mixing a granulated fertilizer in the tilled soil layer, acidification takes place in the soil contiguous to the fertilizer granules (SLOTTA 1981). But because of the high buffer capacity of the soil this is only of minor significance to the plant. A better result is achieved by placing the fertilizer in rows beside the seed row. This depresses the $\mathrm{pH}$ around the fertilizer row to the extent that a remarkable amount of manganese becomes available to plants (Vотн 1978, Vотн and Christenson 1980, WALSH and MCDonnel 1957). In heavily limed soils the availability of manganese to sugar beet can be further increased by addition of manganese sulphate in the acid NPK fertilizer (Vотн 1978, Voth and ChristensoN 1980).

In Finland, manganese deficiency in sugar beet is usually controlled by spraying the foliage with manganese sulphate $(10 \mathrm{~kg} / \mathrm{ha}$ dissolved in $300 \mathrm{l}$ of water) when clear symptoms of manganese deficiency (varicoloured foliage) are observed in late June or early July. Spraying may be repeated after $1-2$ weeks, if necessary.

Leaf application is, however, in many respects insufficient for the control of manganese deficiency. When the plants are small it is difficult to combat manganese deficiency, most of the mixture being wasted because of the small area of the foliage (HALE, WATSON and Hull 1946). Apart from that, spraying is mostly carried out after symptoms of deficiency have been observed. Thus the effect is bound to remain scanty (DRAYCOTT and FARLEY 1973). The sugar beet may have suffered from latent manganese deficiency for a longer period of time before appearance of symptoms. The effect of spraying remains scanty also because there is no internal, between-leaf transfer of manganese (HENKENS and JongMAN 1965). The new leaves developing after spraying may suffer at least from latent manganese deficiency.

Addition of manganese fertilizer in the soil also involves some problems, because manganese rapidly becomes inavailable to plants when mixed into a well limed and tilled soil. Top dressing requires relatively high quantities of manganese with regard to the benefit achieved (DraycotT and Farley 1973).

It seems that the fertilizer placement technique together with acid compound fertilizers would offer a new possibility of economical control of manganese deficiency in sugar beet (Voth 1978, Voth and Christenson 1980, WALSH and McDonnel 1957). The fertilizer placement technique is increasingly being used in Finland and there is an acid $(\mathrm{pH} \mathrm{5.5)} \mathrm{fer-}$ tilizer on the market specifically designed for sugar beet, a sodium containing compound fertilizer (NPKNaB; 13-6-8.5-6-0.2). Kemira Ltd. kindly enough produced a small quantity of this fertilizer with a manganese content of $0.7 \%$ for the present study.

\section{Materials and methods}

The new idea was tested in seven heavily limed old sugar beet fields in 1984-1985. The experiments were carried out in fields which have previously shown symptoms of manganese deficiency (Table 1).

Each experiment consisted of six treatments in quadruplicate:

1. Top dressing $(900 \mathrm{~kg} / \mathrm{ha} \mathrm{Na-containing}$ compound fertilizer) 
Table 1. Soil characteristics.

\begin{tabular}{|c|c|c|c|c|c|c|c|c|c|}
\hline \multirow[t]{2}{*}{$\begin{array}{l}\text { Experimental } \\
\text { site }\end{array}$} & Year & \multirow[t]{2}{*}{$\begin{array}{c}\mathrm{pH} \\
\mathrm{H}_{2} \mathrm{O}\end{array}$} & $\mathrm{P}$ & K & $\mathrm{Na}$ & $\mathrm{Mg}$ & $M n^{1}$ & \multirow[t]{2}{*}{$\begin{array}{c}\text { Humus- } \\
\%\end{array}$} & \multirow[t]{2}{*}{$\begin{array}{l}\text { Soil } \\
\text { type }\end{array}$} \\
\hline & \multicolumn{6}{|c|}{$\mathrm{mg} / \mathrm{l}$} & & & \\
\hline Mietoinen & 1984 & 7.6 & 67 & 165 & 63 & 69 & 12 & 4 & $\mathrm{CL}^{\mathrm{a}}$ \\
\hline Turenki & 1984 & 6.9 & 16 & 140 & 39 & 143 & 12 & 5 & $\mathrm{CL}^{\mathrm{a}}$ \\
\hline Perniō & 1984 & 7.2 & 65 & 136 & 57 & 133 & 13 & 5 & LSC \\
\hline Mietoinen & 1985 & 7.1 & 38 & 226 & 52 & 43 & 8 & 3 & $\mathrm{CL}^{\mathrm{a}}$ \\
\hline Salo & 1985 & 7.3 & 55 & 369 & 40 & 341 & 49 & 8 & $\mathrm{LSC}^{t}$ \\
\hline Köyliô & 1985 & 7.5 & 46 & 80 & 29 & 58 & 5 & 14 & $\mathrm{FL}^{c}$ \\
\hline Perniō & 1985 & 7.4 & 43 & 107 & 37 & 65 & 27 & 3 & $\mathrm{CL}^{\mathrm{a}}$ \\
\hline
\end{tabular}

' $\mathrm{pH}$-corrected $\mathrm{Mn}$ values (Ac-EDTA-extraction)

a coarse loam

b loamy, silty clay

c fine loam

2. Fertilizer placement

3. Top dressing

$(900 \mathrm{~kg} / \mathrm{ha} \mathrm{Na-containing}$ compound fertilizer)

( $900 \mathrm{~kg} / \mathrm{ha}$ Na-containing compound fertilizer + foliage fertilization with Mn a)

4. Fertilizer placement

( $900 \mathrm{~kg} / \mathrm{ha} \mathrm{Na-containing}$ compound fertilizer + foliage fertilization with Mn a)

5. Top dressing $(925 \mathrm{~kg} / \mathrm{ha} \mathrm{Na-containing}$ compound fertilizer with $\mathrm{Mn}$ b)

6. Fertilizer placement

( $925 \mathrm{~kg} / \mathrm{ha} \mathrm{Na-containing}$ compound fertilizer with Mn b)

a) Manganese sulphate $10 \mathrm{~kg} / \mathrm{ha}(\mathrm{Mn} 26 \%$ ) + water $300 \mathrm{l} / \mathrm{ha}$

b) Na-containing compound fertilizer containing manganese sulphate $27 \mathrm{~kg} / \mathrm{ton}$ fertilizer (Mn $0.7 \%)$

The experimental plots consisted of 7 rows, 12 meters each, three midmost rows being harvested ( 20 row meters).

The sugar beet was drilled directly to stand (distance between seeds $15 \mathrm{~cm}$ ). The top dressing plots were fertilized manually before the last tilling. In the placement plots the fertilizer was applied to each row separately, near the seed row (about $3 \mathrm{~cm}$ deeper than the seed row and $6 \mathrm{~cm}$ aside of it) after the last tilling, using a sugar beet fertilizer-seeder.

Spraying with manganese sulphate was carried out immediately after appearance of symptoms of deficiency in the foliage. In 1984, spraying was done in early July and in 1985 in mid-July because of the later seeding period. In each plot the symptoms of deficiency were evaluated visually and samples of mature leaves were taken 10-14 days after spraying. An ash extract was made of dried and ground plant tops. The percentage of manganese in the extract was determined by atomic absorption spectrophotometry.

\section{Results}

Because of the relatively small number of field studies, no correlation could be pointed between the concentrations of manganese in the soil and plants. In the following, only means of the seven experiments are evaluated.

\section{Effect on the quantity and quality of the crop}

The average root yield, percentage of sugar and concentration of impurities of beets are presented in Table 2 . The results indicate that 
Table 2. Effect of the treatments on the quantity and quality of sugar beet yield.

\begin{tabular}{|c|c|c|c|c|c|}
\hline $\begin{array}{l}\text { Treatment } \\
\text { (cf. text) }\end{array}$ & $\begin{array}{c}\text { Root yield } \\
\text { t/ha }\end{array}$ & Sugar - \% & $\begin{array}{c}\text { Amino- } \mathrm{N} \\
\mathrm{mg} / 100 \mathrm{~g} \text { beet }\end{array}$ & $\begin{array}{l}\text { Potassium } \\
\text { meq/ } \\
100 \mathrm{~g} \text { beet }\end{array}$ & $\begin{array}{c}\text { Sodium } \\
\text { meq/ } \\
100 \mathrm{~g} \text { beet }\end{array}$ \\
\hline 1. & $28.2(100)^{\mathrm{a} *}$ & $15.83^{\mathrm{a}}$ & $23.4^{\mathrm{a}}$ & $6.3^{\mathrm{a}}$ & $1.1^{\mathrm{a}}$ \\
\hline 2. & $28.8(102)^{\mathrm{ab}}$ & $15.94^{\mathrm{a}}$ & $24.0^{\mathrm{a}}$ & $6.1^{b}$ & $1.0^{\mathrm{a}}$ \\
\hline 3. & $28.1(100)^{a}$ & $15.91^{\mathrm{a}}$ & $22.3^{a}$ & $6.1^{b}$ & $1.0^{\mathrm{a}}$ \\
\hline 4. & $29.7(105)^{\mathrm{bc}}$ & $15.97^{\mathrm{a}}$ & $24.5^{\mathrm{a}}$ & $6.1^{b}$ & $1.0^{\mathrm{a}}$ \\
\hline 5. & $28.2(100)^{\mathrm{a}}$ & $15.88^{\mathrm{a}}$ & $23.4^{a}$ & $6.3^{\mathrm{a}}$ & $1.0^{\mathrm{a}}$ \\
\hline 6. & $30.8(109)^{c}$ & $15.89^{\mathrm{a}}$ & $24.2^{\mathrm{a}}$ & $6.3^{\mathrm{a}}$ & $1.1^{\mathrm{a}}$ \\
\hline
\end{tabular}

* Numbers in the same columns not marked by a common letter differ from each other at a statistical probability of $95 \%$.

the test factors have affected much more the quantity than the quality of the crop.

Spraying of manganese sulphate did not have a statistically significant effect on the quantity of the crop. The difference between treatments 1 and 3 show the effect of foliage fertilizing when the main nutrients have been applied by top dressing. In such instances foliage fertilizing has resulted in a minor, statistically insignificant decrease in the beet yield ( -0.1 tons $/ \mathrm{ha})$. The difference between treatments 2 and 4 shows the effect of foliage fertilization when the main nutrients have been applied by the fertilizer placement technique. The foliage fertilizer is responsible for a small increase in root yield $(+0.9$ tons $/ \mathrm{ha})$, which cannot be shown statistical significance, however.

It is interesting to observe that compared to top dressing the fertilizer placement technique significantly increases the yield only when foliage fertilizer has also been applied. The results indicate an interaction between the fertilizer placement technique and foliage fertilization.

In the present study, manganese had a strong effect on the sugar beet root yield when manganese was added to NPK fertilizer applied by the fertilizer placement technique. The manganese fertilization is responsible for the difference between treatments 2 and 6 , the increase in the yield being statistically significant $(+2.0$ tons $/$ ha, $+7 \%)$. Top dressing with Mn-containing compound fertilizer has not had any effect.

\section{Effect on symptoms of manganese} deficiency and manganese concentration in plant tops

The fertilizer placement technique most prominently decreased the symptoms of manganese deficiency (Table 3). Foliage fertilization only slightly decreased the symptoms. There was no considerable difference between placement of manganese-containing NPK fertilizer and the conventional NPK fertilizer in favour of the former.

The manganese concentrations in the tops increased by 1.9-fold compared to the control (treatment 1) when the fertilizer placement technique was applied. Placement of manganese-containing compound fertilizer most prominently affected the manganese concentrations in the tops. Manganese concentrations increased by 2.5 -fold (Table 3 ).

Table 3. Effect of the treatments on symptoms of manganese deficiency and manganese concentration of tops.

\begin{tabular}{lcc}
\hline $\begin{array}{l}\text { Treatment } \\
\text { (cf. text) }\end{array}$ & $\begin{array}{c}\text { Symptoms of } \\
\text { Mn deficiency }\end{array}$ & $\begin{array}{c}\text { Mn concentra- } \\
\text { tion of tops } \\
\text { ppm }\end{array}$ \\
\hline 1. & $3.0^{\mathrm{a}}$ & $44^{\mathrm{a}}$ \\
2. & $1.0^{\mathrm{b}}$ & $82^{\mathrm{b}}$ \\
3. & $2.3^{\mathrm{c}}$ & - \\
4. & $0.7^{\mathrm{b}}$ & - \\
5. & $2.0^{\mathrm{c}}$ & $56^{\mathrm{a}}$ \\
6. & $0.8^{\mathrm{b}}$ & $111^{\mathrm{c}}$ \\
\hline
\end{tabular}

Scale $1-10$

2 Numbers in the same columns not marked by a common letter, differ from each other at a statistical probability of $95 \%$. 


\section{Discussion}

The results of the present study clearly indicate that even in Finland manganese deficiency may decrease the sugar beet root yield. Manganese fertilization is necessary especially when symptoms of manganese deficiency are present. Crops exhibiting slight manganese deficiency responded to manganese probably better than expected (DraycotT and FARLEY 1973). The results do not exclude the possibility of latent deficiency causing losses in the beet yield (SPERLINGSSON 1982). Therefore, in the future, tests should be conducted both on fields with no symptoms and on heavily limed fields with apparent symptoms.

Some reports suggest that foliage fertilization should also have shown the effect of manganese fertilization under these circumstances (Draycott and Farley 1973, Draycott and FARLEY 1976). This was, however, not the case, probably because foliage fertilization was applied only once, and possibly too late (FARLey and Draycott 1978).

The results of the study further indicate that manganese would best be available to sugar

\section{References}

Cheng, B.T. \& Ouellette, G.J. 1971. Manganese availability in soil. Soils and Fertilizers 34: 589-595.

Draycott, A.P. 1972. Sugar-Beet Nutrition. 250 p. London.

Draycott, A.P. \& FarLeY, R.F. 1973. Manganese: vital trace element. British Sugar Beet Review 41, 1: 2127.

Draycott, A.P. \& Farley, R.F. 1973. Response by sugar beet to soil dressing and foliar sprays of manganese. J. Sci. Fd. Agric. 24: 675-683.

Draycott, A.P. \& FARLeY, R.F. 1976. Diagnosis of manganese deficiency in sugar beet and response to manganese applications. J. Sci. Fd. Agric. 27: 991-998.

FARLeY, R.F. \& Draycott, A.P. 1978. Manganese deficiency in sugar beet and the incorporation of manganese in the coating of pelleted seed. Plant and Soil 49: $71-83$.

Garcia, C.G. \& Sanchez de LA Puente, L. 1977. The absorption of manganese (III) in oat plants. Plant and Soil 47: 229-237.

Gisiger, L. \& Hasler, A. 1948. Neuere Beobachtungen beet when manganese-containing NPK fertilizer is placed to each row separately (VoTH and Christenson 1980). This would ensure sufficient availability of manganese to sugar beet throughout the growing period. The manganese inside the fertilizer row was somewhat protected against the oxidizing reactions of the soil.

The mechanism of action of the new method of fertilization is not fully clarified. It is assumed that acidification of the soil contageous to the fertilized row has an important role (Voth and Christenson 1980). Placement of fertilizer also promotes the growth of the sugar beet tops; thus the plant secretes more easily soluble organic compounds into the rhizosphere (FARLeY and Draycott 1978, MänTYLAHTI 1981). The organic compounds are oxidized in the rhizosphere and manganese is deoxidized into a plant-available form. The increase in the available manganese by the fertilizer placement technique can also be dependent on the fact that it promotes the growth of the roots, this resulting in the roots sucking up more efficiently even minor quantities of manganese available (DrAYCOTT 1972).

über die Ursachen der Dörrfleckenkrankheit beim Hafer. Plant and Soil 1: 19-50.

Hale, J.B., Watson, M.A. \& Hull, R. 1946. Ann. Appl. Biol. 33: 13.

McHargue, J.S. 1922. The role of manganese in plants. J. Amer. Chem. Soc. 44: 1592-1598.

Henkens, C.H. \& Jongman, E. 1965. The movement of manganese in the plant and the practical consequences. Neth. J. Agric. Sci. 13: 392-407.

Mãntylahtı, V. 1981. Determination of plant-available manganese in Finnish soils. J. Soc. Scient. Agric. Finl. 53: $391-508$.

Scheffer, F. \& Schachtschabel, P. 1976. Lehrbuch der Bodenkunde. 394 p. Stuttgart.

SLotTA, U.M. 1981. Rüben brauchen Bor und Mangan. Zuckerrübe 30: 153-155.

Solov'Ev, G.A. \& Golubev, M.V. 1978. Influence of high mineral-fertilizer application rate and various fertilizer ratios on manganese and iron lability in soddypodzolic soil and the content of these elements in potatoes and fodder beets. Moscow Univ. Soil Sci. Bull. 
33, 2: 48-53.

SPERLINGSSON, C. 1982. Glöm inte mangansprutningen. Betodlaren 45: 118-120.

Vотн, R.D. 1978. Effect of boron, manganese and fertilizers on yield, quality and nutrition of sugar beets (Beta vulgaris L.). Dissertation Abstracts International 39, 3: 1076.

Voth, R.D. \& Christenson, D.R. 1980. Effect of fertil- izer reaction and placement on availability of manganese. Agr. J. 72: 769-773.

W Alsh, T. \& McDonnel, P.M. 1957. The control of manganese deficiency in wheat and oats by the combined drilling of a manganated granulated compound fertilizer. J. Dept. Agric., Dublin 53: 44.

Ms received December 12, 1986

\section{SELOSTUS}

\section{Sokerijuurikkaan mangaaninpuutostilan torjunta sijoituslannoitustekniikalla ja mangaanipitoisella Y-lannoitteella}

\author{
Matti Erjala \\ Sokerijuurikkaan Tutkimuskeskus, \\ 25170 Kotalato
}

Suomessa mangaanin puutetta sokerijuurikaskasvustoista on totuttu torjumaan lehtilannoitteena annettavilla mangaanosulfaattiruiskutuksilla. Suosituksen mukaan, jos selviä puutosoireita (lehtien kirjavoitumista) ilmestyy lehtiin kesä-heinäkuun vaihteen aikoihin, niin kasvusto on syytä ruiskuttaa mangaanosulfaatilla. Sitả käytetảản $10 \mathrm{~kg} /$ ha (Mn $26 \%$ ) sekoitettuna 300 litraan vettä. Ruiskutus uusitaan tarvittaessa $1-2$ viikon kuluttua. Aikaisempien koetulosten sekă kảytănnön kokemusten mukaan lehtilannoitusmenetelmä mangaanin puutteen torjunnassa on osoittautunut kuitenkin monessa suhteessa puutteelliseksi. Lehtilannoituksella on vaikea torjua taimivaiheen aikaisia oireita, sillä pienestä lehtipinta-alasta johtuen suurin osa lehtilannoitteesta menee hukkaan. Mangaanosulfaattiruiskutus vasta oireiden ilmestyessä lehtiin on myös ongelmallista, sillă sokerijuurikas on ennen năkyviă oireita voinut kärsiä jo pitempaaän piilevàstă mangaanin puutteesta. Lehtilannoituksen vaikutus jäă aina osittaiseksi, sillă mangaani ei liiku kasvin sisăllă lehdistă lehtiin. Ruiskutuksen jălkeen syntyvissả uusissa lehdissả voi taas hyvinkin esiintyä ainakin piilevää mangaanin puutetta.

Myös pintalannoitustekniikalla annettu mangaanilan- noitus on pulmallista, sillã maahan lisătty mangaani muuttuu hyvin kalkitussa ja kuohkeassa maassa nopeasti kasveille käyttőkelvottomaan muotoon. Toki maan kauttakin mangaania voidaan antaa, mutta kăyttőmäărăt tulevat silloin epătaloudellisen suuriksi.

Happamesti vaikuttavan Y-lannoitteen levitys rivikohtaisella sijoituslannoitustekniikalla näyttäisi tarjoavan uuden mahdollisuuden torjua sokerijuurikkaan mangaaninpuutostiloja voimakkaasti kalkituilla sokerijuurikasmailla. Seitsemăssă yksivuotisessa kenttăkokeessa (1984-85), joissa esiintyi lieviă mangaaninpuutosoireita, jo pelkkả pintalannoitustekniikan vaihtaminen sijoituslannoitustekniikkaan edesauttoi sokerijuurikkaan kykyä paremmin hyödyntảă maassa olevia mangaanivaroja. Sokerijuurikkaan mangaanin saanti voitiin kuitenkin parhaiten turvata vasta, kun happameen Y-lannoitteeseen lisättiin mangaania $(0.7 \%)$ ja se levitettiin sijoituslannoitustekniikalla. Mangaani sijoitettuna $\left(25-30 \mathrm{~kg} / \mathrm{ha} \mathrm{MnSO}_{4} ; \mathrm{Mn} 26 \%\right)$ yhdessä happamesti vaikuttavan $\mathrm{Y}$-lannoitteen kanssa antoi keskimäärin n. $2.0(+7 \%)$ tonnin juurisadon lisäyksen hehtaarilta mangaanittoman Y-lannoitteen sijoittamiseen verrattuna. 